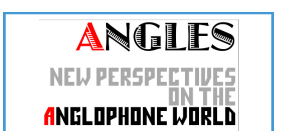

ANELOPHONE WORLI

\section{Angles}

New Perspectives on the Anglophone World

\section{9 | 2019}

Reinventing the Sea

\title{
Three Tsunami Narratives
}

Sonali Deraniyagala's ‘Wave’ (2013), Philippa Hawley's ‘There's No Sea in Salford' (2013) and Minoli Salgado's 'A Little Dust in the Eyes' (2014)

\section{Geetha Ganapathy-Doré}

\section{Q OpenEdition \\ 1 Journals}

\section{Electronic version}

URL: https://journals.openedition.org/angles/1187

DOI: $10.4000 /$ angles. 1187

ISSN: 2274-2042

\section{Publisher}

Société des Anglicistes de l'Enseignement Supérieur

\section{Electronic reference}

Geetha Ganapathy-Doré, "Three Tsunami Narratives", Angles [Online], 9 | 2019, Online since 01 November 2019, connection on 06 June 2022. URL: http://journals.openedition.org/angles/1187 ; DOI: https://doi.org/10.4000/angles. 1187

This text was automatically generated on 6 June 2022

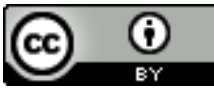

Angles est mise à disposition selon les termes de la Licence Creative Commons Attribution 4.0 International. 


\section{Three Tsunami Narratives}

Sonali Deraniyagala's 'Wave’ (2013), Philippa Hawley's ‘There's No Sea in Salford' (2013) and Minoli Salgado's 'A Little Dust in the Eyes' (2014)

\section{Geetha Ganapathy-Doré}

1 Ancient literature has recorded natural catastrophes, human response to them and the various coping mechanisms mobilized individually and collectively by people. The modern world, in its self-absorption, has forgotten to revisit these stories and learn to enhance its awareness and preparedness. While the ancient Tamil epic Silappatikaram mentions the flourishing portal city of Puhar, another epic, Manimekalai, reports the engulfing of Puhar by the sea after the curse of a goddess. A Chola king, mourning his son's death, had forgotten to celebrate the annual spring festival and this incurred the deity's wrath. The Sri Lankan chronicles Thupavamsa and Mahavamsa speak of a killer wave that was to have swallowed the kingdom of Kelani Tissa. By sacrificing herself, the brave princess, Vihara Mahadevi, appeased the anger of nature that was intended for her father who had ill-treated a Buddhist monk. She was sent in a boat as an offering to the sea. But the sea returned her to safety. What is at stake in both these narratives is human responsibility for the respect of Nature and fellow human beings, and the consubstantial connection between the environment and humankind. Representing Postcolonial Disaster, a research project led by the late Anthony Carrigon at Leeds University, tried to show that "effective disaster mitigation in global contexts depends on thinking through vulnerability in relation to colonial legacies and contemporary neocolonial practices [...] by addressing how postcolonial literature and film can add cultural and historical depth to understandings of catastrophe" (Carrigon 2014: 3-13).

2 The three contemporary narratives on Tsunami in Sri Lanka dealt with in this article share common characteristics: they were all written by women authors; and all three feature a shuttling back and forth between England and Sri Lanka, showing the persistence of the colonial nostalgia for the exotic, on the one hand, and the magnetic force of metropolitan centres, on the other. However, we are witnesses to a postcolonial landscape of complex human relations. In all the three narratives, the critical moment of the tsunami provokes irreparable loss and inevitable change prompting everyone to meditate on the precarity of life on earth. 
3 As Bonie Roos and Alex Hunt observe in their introduction "Narratives of Survival, Sustainability and Justice" to Postcolonial Green: Environmental Politics and World Narratives (2010:1), the undersea earthquake that caused the tsunami in South Asia in 2004 cannot be imputed to global warming. The three narratives under scrutiny are thus primarily stories of human attempts to survive in the face of a natural catastrophe. The biographical element is therefore prominent in the authors' accounts of the coping strategies of the self. While Sonali Deraniyagala has recourse to an autobiographical narrative, Philippa Hawley fictionalizes the biography of an immigrant woman from Sri Lanka. Minoli Salgado, on the other hand, writes an autobiographical novel. Postcolonial fiction biographies, autobiographies, autobiographical novels and autofiction of the $20^{\text {th }}$ century have grappled with the identity crisis at the end of the empires and the conquest of English as the last step in the process of liberation. In the three $21^{\text {st }}$-century narratives studied in this article, physical vulnerability and bodily integrity are at stake. The first theoretical issue arises from the tension between zoe and bio in a context of precarity. Based on the Greek concepts of zoe (natural life) and bio (a particular form of life), Giorgio Agamben defined the concept of "bare life" as "life exposed to death" (1998: 88). Using Agamben's concept of "bare life", Judith Butler developed the idea of "precarious life", observing the fact that all life "can be expunged at will or by accident; their persistence is in no sense guaranteed" (2009: 25). Natural disasters like tsunami and personal upheavals like disease and migratory uprooting are situations which lay bare the precarity of lives, especially women's lives, as attested by the narrative corpus selected for review. The women protagonists wonder how they can retrieve a life worthy of living after it has been transformed by grief.

4 The overcoming of bodily injury and the risk to life recounted in these $21^{\text {st }}$-century narratives constructed around the 2004 tsunami that devastated parts of South and South-East Asia warrants comparison with the trauma narratives of the $20^{\text {th }}$ century. At the end of the Second World War, survivors of the Holocaust resorted to writing about the humiliation, isolation, and deprivation they were victims of in order to overcome their trauma. Cathy Caruth (1996), Ruth Leys (2000), Didier Fassin, Richard Rechtman \& Rachel Gomme (2007), and Roger Luckhurst (2008) have proposed theoretical approaches of the trauma narrative, one that helps victims make sense of their painful experience through jumbled but remembered sounds, colours and emotions. One of the issues dealt with in such narratives is the question of survivor's guilt - the guilt associated with being alive when others have died, the guilt of having failed the others, and the guilt of what one did in order not to die (Bettelheim 1980: 297-8). Another aspect of trauma narratives is memorialization and the duty to remember, which is both individual and collective (Blustein 2017: 351-362). Depending upon the cause of the trauma, which is either inflicted by nature or mankind, the texts studied do not treat survivor's guilt and the duty of memory in the same way.

5 The end of wars and empires have been the occasion to voice human and humanitarian concerns about the right to life, freedom from slavery and torture and protection of the vulnerable like women, children and the aged. The distinction between the trauma narrative and the humanitarian narrative - in which the representation of suffering is central to "the mobilization of sympathy for humans in severe distress" (Libal \& Martinez 2011:162) - needs to be made using the idea of compassion as a touchstone. 
Natural catastrophes are contexts in which social, gender, and racial hierarchies put in place by patriarchy, colonialism, and nationalism are jostled and power struggles resurface. The three narratives are test cases to see how these issues play out locally and globally and how writing - memoirs, letters, theses, records of human rights - is chosen as the preferred mode of subaltern agency.

Natural disasters induce environmental change. Sometimes it is environmental change that provokes natural disasters. Whatever the event, symbolic national boundaries collapse to reveal humanity's search for safety and security. When the environment is incorporated in the narrative not as a mere setting but as a force to reckon with, the postcolonial focus on the meaning of home backslides to the idea of habitat. The three texts serve as testimonies to the realization that the fixedness of a place to live can no longer be taken for granted. They attest to the shift from a psychological to an ecological orientation of reality in the contemporary world.

With these theoretical and overall considerations in the background, the article aims to provide an individual and close reading of the three tsunami narratives to analyze what they tell us about gender, family, ethnic, and race relations in times of personal, political and natural turmoil and explore how a pathway to peace is found across the geography of pain in these intimations of mortality.

\section{The Hour of Lead Outlived and Remembered - Sonali Deraniyagala's Wave}

9 Sonali Deraniyagala's récit has all the trappings of a trauma narrative. ${ }^{1}$ As Cathy Caruth points out, "trauma is not locatable in the simple original or violent event in an individual's past but rather in the way that its unassimilated nature [...] returns to haunt the survivor later on" (Caruth 1996: 4). Deraniyagala's American psychotherapist, Mark Epstein, persuaded her to write. With Epstein's combination of Buddha's and Freud's approaches to trauma in his treatment of Deraniyagala (Epstein 2013), she presents her life story as a contemporary fable about the limits to the regularity and predictability of life on earth.

10 The daughter of a Sri Lankan lawyer, Deraniyagala meets Steve Lissenburgh, who comes from an East London working class family of Dutch origin, in Cambridge in 1984. They marry in 1988, have two children, Vikram and Nikhil, and live in Sri Lanka for two years where Steve teaches economics in a school. They return to England to complete their PhDs and set up their home there, making bi-annual trips to the island. The whole family is fond of the wildlife of the earthly paradise that is Sri Lanka. During one such three-week visit to the Yala national park during Christmas in 2004, the family tries to escape the incoming sea in a jeep not knowing it is a tidal wave. The jeep is tilted by the force of the wave and when Deraniyagala comes back to herself hours later, she finds herself in a shattered landscape. Her husband, sons, parents and friend are all gone. For Sonali, it is a descent unto hell, the beginning of self-alienation.

11 Published in 2013, the narrative is organized into 9 chapters covering the 9-year period between 2004, the year of her loss, and 2012, the year of reconciliation with the loss with flashbacks to the Sri Lanka of the 1970s and the England of the 1980s.The book's opaque black cover symbolizes both the kala pani $i^{2}$ as well as mourning. The minimal, two-syllable title of the book tries to highlight the life-altering and overwhelming 
nature of a brief but brutal moment. ${ }^{3}$ The way the four letters of the title change colours and brighten shows the slow passage from darkness to light that any recovery implies (see Figure 1). Sonali Deraniyagala has admitted that her process has been to gradually open up the wounds. "I wrote for a long time purely for myself [...] The writing was my survival actually. [...] It was my way of being with them. The more I wrote, the more real they became to me." (quoted in Barber 2013)

Figure 1. Cover of Sonali Deraniyagala's Wave (2013)



SONALI DERANIYAGALA

12 The narrative starts with the description of the tidal wave (W3). ${ }^{4}$ The progressive invasion of land by the sea is suggested in the text by what E. A. Gamini Fonseka has identified as "melodic truth," borrowing the concept from Milan Kundera (Fonseka 2017:146).

The foam turned into waves. Waves leaping over the ridge where the beach ended. This was not normal. The sea never came this far in. Waves not receding or dissolving. Closer now. Brown and gray. Brown or gray. Waves rushing past the conifers and coming close to our room. All these waves now, charging, churning. Suddenly furious. Suddenly menacing. (W5)

13 Deraniyagala is swept inwards and outwards by the water but manages to hold on to the branch of a tree. She is in a daze when she is rescued. It is only at the end of the narrative that her friend tells her how her rescuers found her spinning, as if she were in a mystic trance. This again confirms Caruth's observation that victims of trauma unwittingly reenact the traumatic event that they are not able to leave behind (Caruth 1996: 2).

14 Deraniyagala is not able to make a break between before and after the crisis, and wants to stay suspended in time. According to Boris Cyrulnik (2012), disturbance of the sense of time is a form of post-traumatic stress disorder. The failure of the self to cope with disruption, discontinuity and absence is worsened by survivor's guilt. Deraniyagala 
blames herself for not having warned her parents about the impending danger, for not having been able to protect her children, and for hurting Steve's family and friends by bringing him and the children to Sri Lanka and exposing them to danger. In recent times, the idea of survivor's guilt in Holocaust narratives has been challenged because it involves the victim's unconscious identification with the perpetrator and collusion with power (Leys 2007: 5). In a natural catastrophe, where there is no human agency inflicting pain, what predominates is a sense of shame and loss of dignity. Deraniyagala adopts a strategy of avoidance as she refuses to identify the dead bodies at the hotel and postpones her looking for her near and dear - she is in denial. Submerged by rage, she cannot even grieve.

She first attributes her personal tragedy to her hubris, taking the good things in life for granted. Then she is overcome with a sense of culturally-inherited guilt, i.e., the Buddhist belief in the idea of Karma, which makes her think that her survival in such circumstances is a punishment, an invitation to cleanse her past sins by undergoing this bitter experience (or dukkha in Buddhism). However, when the London Evening Standard rubs salt in the wound by reporting that

Dr Sonali Deraniyagala, a 40-year-old academic, watched in horror as her husband Dr Steve Lissenburgh and two sons were engulfed by the water as they tried to flee in the family's holiday car. (David and Gilligan: 2005)

she becomes aware of the subaltern status to which she has been relegated. To say that she "watched in horror" is to disassociate her from the critical scene and give her agency where she did not have any means to act, and responsibility for the death of her English husband in her native Sri Lanka. This othering process, which may be read as a sign of resurgence of colonial prejudices, overwriting her point of view with the journalists' narrative, allows them to not recognize her as a victim too, albeit one who survived the tsunami.

In the early stages, tossed between the need to remember and the necessity to forget, Deraniyagala is in a state of stupor, bangs her head, smashes things, inflicts wounds upon her body, burns herself with cigarette stubs, gets drunk, takes drugs in the hope of committing suicide. Haunted by the sights, sounds and memories of her loved ones, she wants to become a specter herself and harasses the people who had rented her parents' house in Colombo. In the light of recent scholarship, such self-destructive behavior can be interpreted as a trauma victim's "embodied expression of pain" (Gurung 2018: 32).

18 Loving relatives look after her and keep her physically alive. But trauma is a mental wound which has not only temporal but also spatial implications. Dylan Trigg has argued that "the place of trauma and the subject of trauma form a structurally parallel unity" (2009: 88). The different journeys Deraniyagala's in-laws and friends make to Sri Lanka, the ritual of memorial services, the identification of the bodies, the retrieval of parts of objects that belonged to her lost ones from the site of the tragedy, the different journeys that she herself makes to England, avoiding her home at first, only setting foot there after almost four years, the remembering of the departed ones in concentric circles - first her children, then her husband, and then the parents - help her spiral her way out of grief and accept the reality of death. Only in the desolate icy landscape of sub-arctic Sweden, far removed from the place, site and scene of her traumatic experience, is she able to find some peace and tranquility. Similarly, the sight of two "otherworldly blue whales" (W186) she watches along the Mirissa coast in Sri Lanka 
finally heals her. It is thanks to her "nature connectedness" (Lumber et al. 2018) that Deraniyagala is able to reconnect with her livable life.

When Deraniyagala moves to the US to take up research, this third space helps her set up the right distance from both England and Sri Lanka and start the work of redefining herself. She is now willing to reconcile herself with the children's storybook identity her younger son Malli had attributed to her, "Mummy Lissenburgh" and which she, as a feminist, had found objectionable. While accepting the PEN/Ackerly Prize for her book in 2014, Deraniyagala remarked: "There is a beauty in struggle and a resting place in the eyes of others [...] I have found myself a writer, another identity in the ongoing bewildering journey of my life." (Quoted by Travis 2018) In a trauma narrative, compassion from others works essentially as a pathway to self-compassion.

Deraniyagala qualifies her story telling as a "coming out" (W105) which shows us how a person who has survived an immense danger and unimaginable loss internalizes herself as a totally scarred person capable of frightening others by the monstrosity of her suffering. According to Caruth, it is in the very nature of the trauma narrative to defy and demand our witness. [...] [It] tells us of a reality or truth that is not always available. This truth in its delayed appearance and belated address, cannot be linked only to what is known, but also to what remains unknown in our very actions and language. (Caruth 1996: 4)

21 Writing a memoir can be seen as Deranyagala's speech act during which her selfdisclosure as a victim liberates her from shame and self-imposed isolation. The empathetic reader understands the anger, the feeling of powerlessness and the impulse to destroy that are conveyed in the words of insult not proffered but inwardly pronounced by Deranyagala in the text and forgives her. It is this secular redemption that she seeks by daring to tell the untellable to a variety of listeners. When her husband Steve was alive, he was fascinated by the statue of the Sri Lankan Buddhist Goddess Tara in the British Museum (Figure 2) and the varadamudra of her right hand (gesture of giving). The benevolent Goddess Tara does not protect him in the moment of crisis. It is his wife who carries centuries of unconscious knowledge of the land embedded in her who survives. Her very survival makes her transcend her human condition and acquire an almost mythical dimension. 


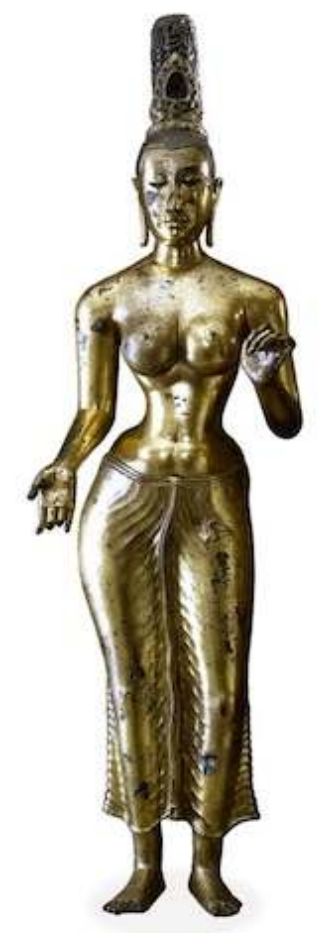

Source: https://media.britishmuseum.org/media/Repository/Documents/ 2014_10/1_6/68b2cd63_7ab2_4aa7_930a_a3b7006954bd/mid_00031550_001.jpg

Malli, the author's 5-year-old son, concocts a story about his true family in America. It consists of his mother Sue, Father Tees and Sister Nelly. They all die eaten by a lion in an African jungle (W138). Malli's invention of an alternative family in a third country might have been prompted by his postcolonial parents' telling him that he has two homes (W151), one in England and one in Sri Lanka, and his fantasy of a fixed place of his own that he desires as a cross-cultural child. Deraniyagala uses her son's story to illustrate the power of stories to help human beings face the unknown and the uncertain. While she is receptive to the cognitive function of storytelling, her mother pays more attention to its potential to penetrate the supernatural. She thinks that Malli is remembering his past life and wants to perform an occult ceremony to moor him to this life.

The tremendous interest generated by Wave cannot be explained by the simple human psychology of a few miserable people wanting to feel good by comparing their lot with the harsher one of others, or by the attention provoked by global media coverage. It is an indication of how contemporary human psyche has been sensitized to the deterioration of the environment as an immediate, real and universal menace to life on earth. Deraniyagala's narrative is akin to a Greek tragedy in that it validates the role of the inexorable force of the non-human in the conduct of human lives, in this case with the primordial form of a wave. The narrative's aesthetics of ruin and silence contributes to its elegiac tone. Deraniyagala's real-life wedding to British actress Fiona Shaw in March 2019 provides closure to this story of self-transfiguration by grief. 


\section{There's No Sea in Salford - The Humanitarian Narrative}

There's No Sea in Salford (2013) is a self-published first novel by Philippa Hawley, a retired general medical practitioner from Essex. In 1978, she worked in Sri Lanka for three months and developed a love for the land. Her novel, comprising fifty short chapters, is a plain but gripping narrative written in the third person that incorporates some flashbacks. Its form is hybrid, with elements of a memoir in which the author's fictional double called Penny opens a personal diary and recalls her three months' stint in Sri Lanka as a medical student with her friend Jean, combined with the fictional biography of Kiri de Souza, a Sri Lankan medical assistant who migrated to the UK as the legal wife of an Indian Tamil surgeon, the epistolary novel and a profession-based fiction of healing after catastrophes, personal and natural. Thanks to the transnational concerns it encodes, this novel clearly falls within the emerging genre of the humanitarian narrative. It takes for granted what Didier Fassin calls the "humanitarian reason", in other words, "moral sentiments" that direct our attention to the suffering of others and make us want to remedy them (Fassin 2012: 1). While the trauma narrative is keyed to the empathetic component of compassion, the humanitarian narrative rests on its sympathetic component.

Figure 3. Cover of There's No Sea in Salford by Philippa Hawley



The tsunami that struck the island along with Southern India and Indonesia on Boxing Day 2004 is the event that helps both Penny and Kiri to contact each other and reconnect with Sri Lanka. The title of the novel comes from a remark that Kiri de Souza makes to her brother-in-law about her dead husband's ashes. "There are no sacred rivers [...] There isn't even any sea in Salford" $(\mathrm{S} 136)^{5}$ to disperse them, showing the extent to which Kiri has imbibed and internalized both the maritime geography of her 
childhood in Batticaloa and her husband's Hindu culture which holds waterbodies sacred.

The novel opens with the depiction of Kiri de Souza's extremely disturbed physical state when she hears about the tsunami on the radio and worries about her lone mother's safety. It is as if the ripples of the killer wave had come as far away as Salford to touch her. Parallel to this indoor scene, Hawley paints the outdoor picture of Penny learning about the tsunami in a motorway while driving to Northampton for Christmas celebrations. Her husband Clive stops the car as if to suspend time in order to help his wife, who had been nursing a desire to return to Sri Lanka for 27 years, recollect herself. Penny telephones her friend Jean and they decide to locate Kiri who had accompanied them during their sight-seeing trips in Sri Lanka. They knew she had settled in England but had lost touch with her.

Despite the fact that, during the civil war on the island, the Sinhalese majority tried to contain the Tamil minority, in England it is the Sinhalese Kiri who remains an extremely vulnerable woman, locked in an unhappy marriage to a Tamil, Raja Coomaraswamy. Raja abuses her, treats her like a slave and keeps her isolated, virtually in house arrest. What is more, she is a betrayed wife as her husband had hidden that he had an official fiancée before the marriage and later kept a mistress and even fathered a son. She is also a bereaved mother who lost her baby after an 18-week pregnancy which left her sterile. She is, to boot, a cancer patient who lost one breast to the disease and, with it, her confidence as a woman. She embodies the syndrome of "a poor woman and a stranger" because her husband would not let her take a job and confiscated her passport and thus her freedom. In other words, Kiri is an allegory of precarious life.

The novel draws a subtle comparison between the tsunami, which is a natural catastrophe, and the physical and social catastrophes that affect Kiri: disease and a failed marriage. Kiri fights back and recovers from the disease, but she is not able to emancipate herself from her husband's clutches. It is his lack of humanity after the tsunami, refusing to take Kiri to see her surviving mother, refusing to send her the money that he promised to send, which prompts Kiri's rebellion. She chooses to break the walls of her prison by writing letters to her mother and Penny. Though intended as a therapeutic exercise, writing letters in a confessional mode is what enables Kiri to recover her agency. When she gathers the courage to tell her story to Shelley, the social worker, it is as if a dam was broken and the flood of suffering was unleashed. As Penny and Jean come to her rescue through a common doctor friend, Raja retreats from violence like a receding tide.

Relief comes to Kiri in the form of the accidental death of her husband. With the help of all the institutional actors in the English system (doctors, nurses, social workers, policemen, coroners, funeral service providers, solicitors, charity volunteers) and their commitment, she is able to cremate her husband, liquidate his estate and return to Batticaloa to see her mother. Kiri's duty of memory towards her community helps her sublimate her necessity to forget a husband who had tormented her. She sets up a charity called "Pearls across the Sea" to help orphaned and damaged children who study at St. Mary's Mission School where her aged mother, Lali de Souza, works as a cook. This enterprise changes Kiri's status from a pathetic to a heroic victim.

The hovering presence of death haunts the novel: Pauline, Kiri's friend and cancer patient whom she meets at the hospital, dies a dignified death; each time Kiri goes for a consultation about a tumour, she expects a death sentence; Sam, the friendly 
entrepreneur, who helps Kiri build the nursery school for the charity, loses his elder son to the civil war and his wife to the tsunami; Raja is killed in an accident. But, as a doctor, Hawley takes care to articulate a discourse of healing by showing that Kiri's return to Sri Lanka signals her rebirth. Kiri is reunited with her mother after both of them have withstood crises of their own. When her mother realizes the extent of trauma that her daughter has gone through, she forgives Kiri for her rebellious marriage and her abandoning her family and home country. This moment of transgenerational reconciliation serves as a stepping-stone for reconstruction - of their lives, the school as well as their country. As a survivor of tragedy, the aged Lali symbolizes resilience. The parallel constructed by the author between her and the strong banyan tree near the school, which was not uprooted by the tsunami and which stands as an immovable sign of continuity and comfort (S189), makes Nature the good mother. Kiri learns resilience from both Nature and her mother when she has to recover from physical exhaustion and failure, and accept the love of Sam to start her life anew.

31 The novel ends with the staging of female solidarity and celebration of the cause of education that cuts across the boundaries of geography, race and class. Kiri, her husband's former lover, Charmina Patel, to whom he had left some money in his will, Penny, Jean, Shelley and the headmistress of St. Mary's school, all join hands to inaugurate the new dormitory and nursery of the "Pearls across the Sea" charity. They testify to the triumph of the humanitarian instinct over personal or political considerations. Hawley offers some saving grace in Raja by evoking the discrimination he had faced in his professional life as a migrant in England, compared to his more successful brother Rupesh who settled as a dentist in Canada. It is Rupesh who acts as an instrument of social justice by agreeing to pay a stipend for Raja's child from his inheritance of the third part of his brother's estate.

Readers might find Hawley's picture-postcard Sri Lanka and the sense of middle class comfort that shows through in her narrative rather ambivalent and her "emergency imaginary", i.e. believing and portraying the possibility of effective and ameliorative action (Calhoun 2006), rather uncritical. Readers might be tempted to label her work as part of the spectacle of "Suffering at distance" denounced by Luc Boltanski (1999). They might even dismiss it as a rehashed patient's case history. But Hawley's is by no means an interventionist gesture. The fact that she has published a second novel on disability and adoption in 2015, How They Met Themselves (named after a painting by Dante Gabriel Rossetti) shows Hawley's writing practice to be "glocal" and a sign of empowerment of women rather than a mere pastime.

\section{Minoli Salgado's A Little Dust in the Eye - A Memorial Narrative of Postponed Mourning}

33 Though Minoli Salgado's A Little Dust in the Eye (2014) is the latest of the three narratives from a chronological point of view, it ends with the tsunami scene. The evocation of the post-tsunami landscape remains rather brief. In spite its being a third-person narrative, the focalization on Savi, one of the two female protagonists, a Sri Lankan academic in England like the author, makes the novel almost autobiographical. The other protagonist is Savi's cousin Renu who, because she has Saturn in her seventh 
house of marriage, chooses to remain single and becomes involved in rehabilitation work on the island.

Figure 4. Cover of $A$ Little Dust in the Eye by Minoli Salgado

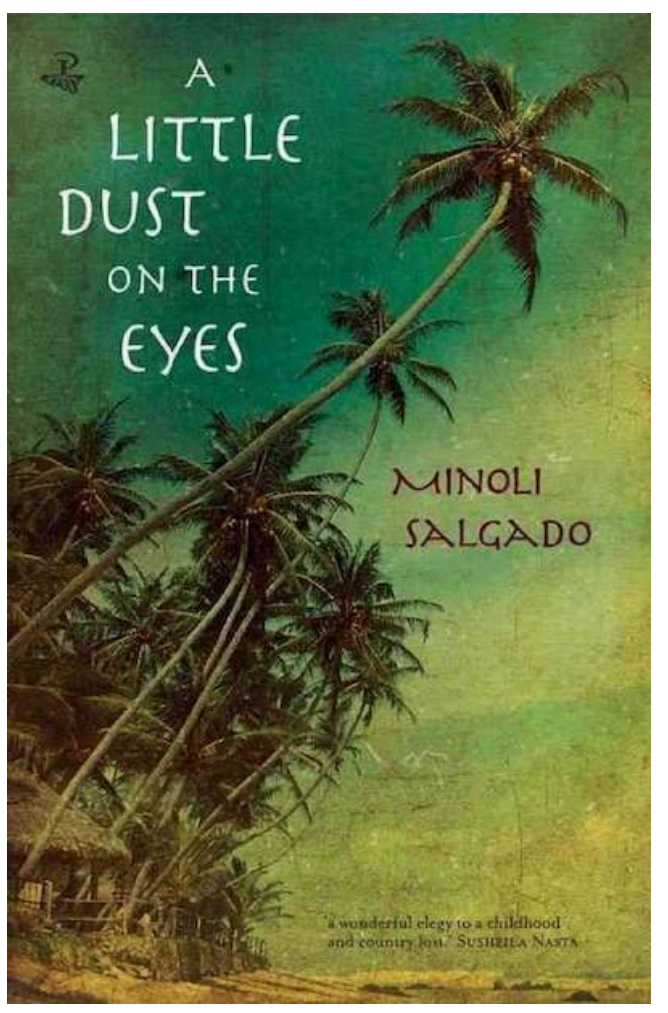

The title of the novel is a quote of Buddha's words, cited by Pankaj Mishra is his parttravel, part-philosophical memoir Buddha, An End to Suffering (Mishra 2004: 214), which refers to people whose gaze is somewhat perturbed. The embedded intertextual model is a Holocaust narrative by Jona Oberski entitled Childhood (2014) that Savi carries all the way to Sri Lanka. As the quintessential trauma of recent human history, the Holocaust experience has shaped many of our understandings of personal and collective trauma, as Anna Hunter observes ( 2018: 66-82). The symbolic presence of the Holocaust narrative in Salgado's novel is a pointer to something unspeakable that the narrator is going to reveal later, i.e. the destruction of childhood and forced disappearances as "human wrongs" (Spivak 2004: 523). It is Natalie, the child of Savi's friend Hannah, who tells her to go back to Sri Lanka while they are relaxing on the beach at Brighthelm. Natalie can thus be seen as a shadow of Savi's memory of herself as a child.

The strategy of using two protagonists helps the narrator articulate a stereoscopic vision. The several layers that build this complex memorial novel of postponed mourning are:

1. The story of the two Rodrigo brothers - Renu's father Edward, who marries Fiona, an English woman, and runs a hotel; and Savi's father Dominic, a lawyer who marries a local woman. Dominic is considered as a traitor because he defended the Tamils during the civil war.

2. The story of Savi's childhood trauma, with her mother dying of illness, her expatriation to England, and her father's disguised suicide. 
3. The story of Savi's several journeys to Sri Lanka: on the occasion of her father's death, during a visit with her husband Rob, and during a family visit to attend her cousin's marriage and reclaim her heritage.

4. The story of Savi's writing a thesis in England on the folktales of Sri Lanka, especially The Manticore's Tale.

5. The story of Renu's unfulfilled love for Kitsiri, her brother's friend, a soldier in the Sri Lankan army, and her subsequent metamorphosis into a human rights activist and writer.

6. The vendetta of Bradley Sirisena whose trade unionist father is abducted and killed by Kitsiri.

7. The construction of archives by the human rights activist Navin Ranatunga.

former self. This is symbolized in the novel by the letting go of the child who clings to Savi during the tsunami and whose detached weight unsettles the adult woman and drowns her as well. Talk about a "mobile sense of belonging" makes sense only in closed seminar rooms as the narrator ironically remarks (LDE82). Savi had glimpsed an 
unknown body floating in the river while visiting Sri Lanka upon her father's death. As a child, she did not explore the truth of it. As an adult, when she associates a name (that of Sirisena's father) with the dead body, she realizes how she too has been unwittingly part of the violence that had engulfed the island. For a migrant, retrieving lost childhood is always already a risky task. When the tremendous force of time has flooded the murky waters of memory, both the body and self are erased.

Contrary to Renu, who looks for a good story among muddled facts, the narrator of $A$ Little Dust in the Eyes gives detailed facts about the tsunami (LDE208) among multiple and intertwined stories. The energy released by the tsunami was equivalent to 23,000 atomic bombs. The narrative camera pauses on two physical memorials built to remember the victims. One, containing white steel crescents, is deemed poetic and polysemic by Renu as it performs the duty of memory regarding all the victims. The other, commemorating a capsized train, contains inscriptions in English that are "meant for foreigners" (LDE226). Renu's decision to write her own version of the country's human rights record may be viewed as her way to counter the hijacking of the duty of memory by the country's political elite who perpetuate colonial dependence.

41 A Little Dust in the Eyes is also the only tsunami narrative where the story of Vihara Mahadevi is beautifully retold from the subaltern point of view by the domestic help Josilin. Vihara Mahadevi is the selfless daughter, a counter figure to Sinhabahu, ${ }^{7}$ the lion-father who punished his son and paved the way for the latter-day Sinhala nationalism (Figure 5). The novel ends with a picture of the surviving Renu writing and reenchanting the world. The embedding of the folktale of Vihara Mahadevi (Figures 6 and 7) in the novelistic text allows Salgado to simultaneously contest the dominant and founding myth of the nation tainted by violence, to empower the female storyteller, and to propose an anti-patriarchal and alternative national myth in which resilience is upheld, rather than violence. Salgado offers a narrative remedy to the political ills of a nation where human rights are in peril.

Figure 5. Flag of Sri Lanka featuring Sinhabahu, the legendary king



Source: https://commons.wikimedia.org/wiki/File:Flag_of_Sri_Lanka.svg 
Figure 6. Representation of the mythical figure of Viharamahadevi (as a princess) near the Dagoba in Tissamaharama

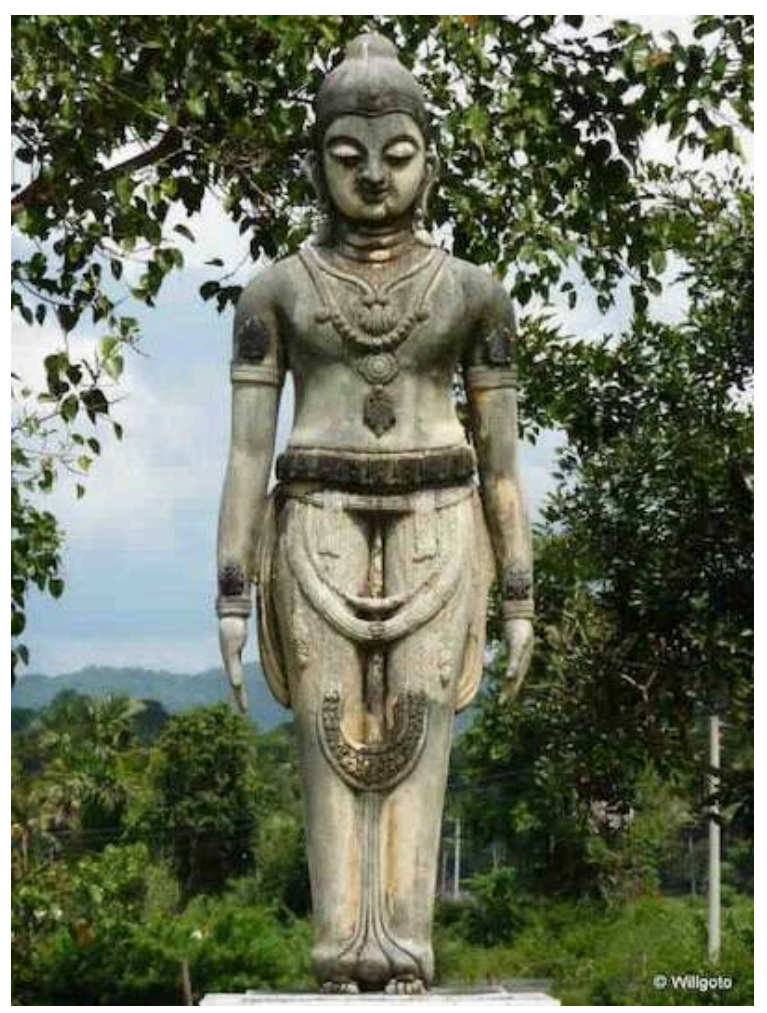

Source: http://www.willgoto.com/images/Size3/

Sri_Lanka_Tissa_P1020391_a10b68bdb856433495d2bd3ddb13a71c.JPG 
Figure 7. Representation of Viharamahadevi almost as a female Buddha in Colombo, Viharamahadevi Park

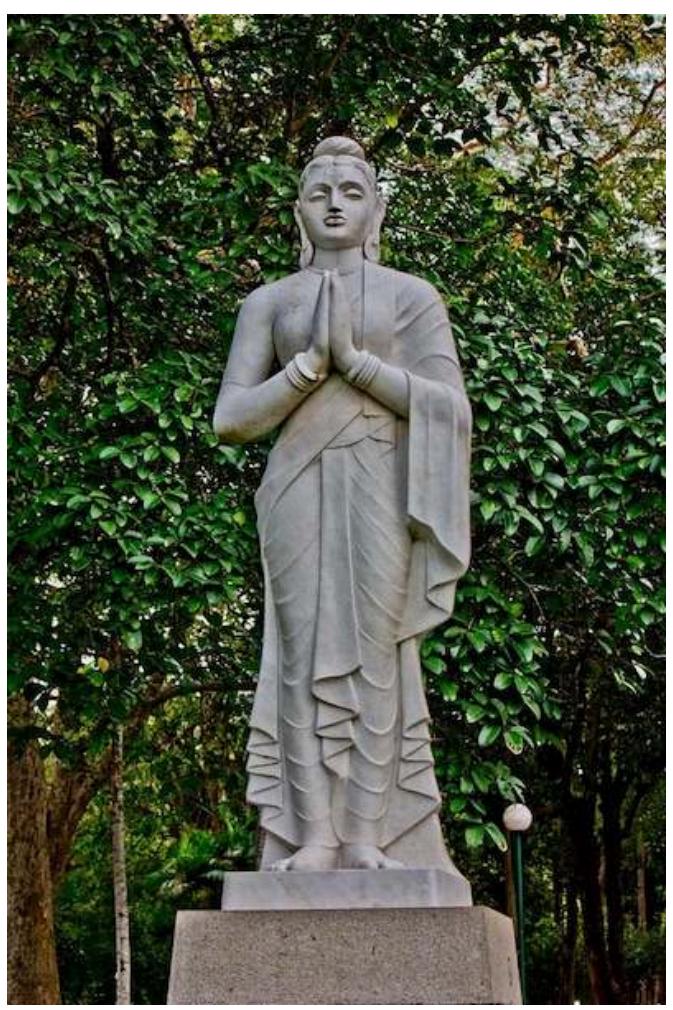

Source: https://en.wikipedia.org/wiki/Viharamahadevi\#/media/File:Queen_Viharamahadevi.jpg

\section{Nature and Gender}

In all three narratives, nature is represented in its nourishing and sustaining role as well as a terrifying force of havoc and death. The very same wilderness of Nature in Sri Lanka that fascinates metropolitan visitors from England becomes a wasteland because of the dark and demonic power of the wave. The description of the debris in all three narratives gives a glimpse of what awaits humanity if humans forget the place of nature in their lives. However, nature's power to revive and rejuvenate is visible in the fresh green shoots that sprout in the jungle and the birth of birds. It is mirrored in the strength of women, their resilience, their capacity to rebuild their lives and tell their stories.

43 While Salgado's narrative is overtly feminist, the other two texts discussed in this essay adopt a more balanced approach to gender. The family unit, whether nuclear, extended or recomposed, comes off as fundamental for peace and happiness. The superhuman dimension of the tsunami helps both the insiders and outsiders to look beyond ethnic fratricide and tense race relations. Whether it is through a commitment to ecology, Christian charity or Buddhist detachment, a path to peace, however provisional it may be, is found in all three narratives because, in the words of Shakespeare in Cymbeline, "Golden lads and girls all must, / As chimney sweepers come to dust." 


\section{BIBLIOGRAPHY}

Agamben, Giorgio. Homo Sacer: Sovereign Power and Bare Life. Stanford: Stanford UP, 1998.

Barber, John. "Sonali Deraniyagala's tsunami memoir: One of the saddest stories a human being could ever tell." The Globe and the Mail, March 19, 2013. https://www.theglobeandmail.com/arts/ books-and-media/sonali-deraniyagalas-tsunami-memoir-one-of-the-saddest-stories-a-humanbeing-could-ever-tell/article9956880

Bettelheim, Bruno. Surviving and Other Essays. New York: Vintage Books, 1980.

Blustein, Jeffrey. “A Duty to Remember.” In Sven Bernecker \& Kourken Michaelian (ed.), The Routledge Handbook of Philosophy of Memory. London and New York: Routledge, 2017: 351-62.

Boltanski, Luc. Distant Suffering: Morality, Media and Politics. Cambridge: Cambridge UP, 1999.

Butler, Judith. Frames of War. When is Life Grievable? London: Verso, 2009.

Calhoun, Craig. "The emergency imaginary: humanitarianism, states, and the limits of cosmopolitanism." University Professorship Inaugural Lecture. 15 November 2006. New York NY, USA. (Unpublished).

Carrigan, Anthony. "Introduction: Representing catastrophe." In Moving Worlds: A Journal of Transcultural Writings 14-2 (2014): 3-13.

Caruth, Cathy. Unclaimed Experience. Baltimore: Johns Hopkins UP, 1996.

Cyrulnik, Boris. La mémoire traumatique. Conférence. Université de Nantes. 26 November 2012. https://webtv.univ-nantes.fr/fiche/2639/boris-cyrulnik-la-memoire-traumatique

David, Luke and Gilligan, Andrew. "Parents tell of son's fight for safety." Evening Standard, 12 January 2005, https://www.standard.co.uk/news/parents-tell-of-sons-fight-forsafety-7250547.html

Deraniyagala, Sonali. Wave. London: Virago, 2013.

Epstein, Mark. The Trauma of Everyday Life. New York: Penguin Press, 2013.

Fassin, Didier, Richard Rechtman \& Rachel Gomme. The Empire of Trauma - An Inquiry into the Condition of Victimhood . Princeton: Princeton UP, 2009.

Fassin, Didier, Richard Rechtman \& Rachel Gomme. Humanitairian Reason, A Moral History of the Present. Trans. Rachel Gomme Berkeley, U of California P, 2012.

Fonseka, E. A. Gamini. "Female Resilience in the Face of Family Tragedy: A Comparative Study of Sonali Deraniyagala's Wave and the Buddhist Tale of 'Bhikkhuni Patachara."' In Gamini Fonseka, P.K.M. Dissanayake \& Upali Pannilage (eds.). Avenues. Papers on Peace, Reconciliation and Development Challenges, Proceedings of the 2nd International Conference on Humanities and social sciences. Faculty of Humanities \& Social Sciences, University of Ruhuna, 2017: 142-157. https:// www.researchgate.net/profile/Pannilage_Upali/publication/ 317661438_Avenues_Peace_Reconciliation_and_Development/links/5947987faca27242cda1cbe9/ Avenues-Peace-Reconciliation-and-Development.pdf\#page $=142$

Gurung, Kesherie. "Bodywork: Self-harm, trauma, and embodied expressions of pain”. In Arts and Humanities in Higher Education 17-1 (2018): 32-47.

Hawley, Philippa. There is No Sea in Salford. Colchester: Wiven Books, 2013. 
Hunter, Anna. “The Holocaust as the Ultimate Trauma Narrative." In J. Roger Kurtz (ed.), Trauma and Literature. Cambridge: Cambridge UP, 2018, 66-82. Doi: 10.1017/9781316817155.006

Levi, Primo. The Drowned and the Saved. New York: Simon \& Shuster, 1988.

Leys, Ruth. Trauma. A Geneology. Chicago: U of Chicago P, 2000.

Leys, Ruth. From Guilt to Shame: Auschwitz and After. Princeton: Princeton UP, 2009.

Libal, Kathryn, and Samuel Martinez. "Introduction: The Genre of Humanitarian Narrative." Humanity Journal June 10 (2014). http://humanityjournal.org/issue2-2/introduction-the-genderof-humanitarian-narrative/

Luckhurst, Roger. The Trauma Question. London and New York: Routledge, 2008.

Lumber, Ryan, Miles Richardson, David Sheffield. "The Seven Pathways to Nature Connectedness: A Focus Group Exploration." In European Journal of Ecopsychology 6 (2018): 47-68. http:// eje.wyrdwise.com/v6/EJE\%20v6_Lumber\%20et\%20al_minor\%20edit.pdf Mishra, Pankaj. An End to Suffering Buddha in the World. London: Farrar, Straus and Giroux, 2004. Oberski, Jona. Childhood. London: Penguin Classics, 2014.

O'Loughlin, Liam. “'A Different Way of Seeing': An Interview with Minoli Salgado Conducted over Email and Skype between 19 June 2015 and 3 September 2015”. ariel: A Review of International English Literature 47-4 (2016): 163-173. Doi: 10.1353/ari.2016.0036

Roos, Bonnie \& Alex Hunt. Postcolonial Green: Environmental Politics \& World Narratives. Charlottesville: U of Virginia P, 2010.

Salgado, Minoli. A Little Dust in the Eyes. Leeds: Peepal Tree, 2014.

Spivak, Gayatri-Chakravorty. "Righting Wrongs.” South Atlantic Quarterly 102-2/3 (2004): 523-581. Doi: 10.1215/00382876-103-2-3-523

Suleri, Sara. The Rhetoric of English India. Chicago: Chicago UP, 1992.

Travis, Ben. "Sonali Deraniyagala wins the 2014 PEN/Ackerley Prize for tsunami memoir." The Telegraph, 15 July 2014. https://www.telegraph.co.uk/culture/books/bookprizes/10968116/ Sonali-Deraniyagala-wins-the-2014-PENAckerley-Prize-for-tsunami-memoir.html

Trigg, Dylan. "The place of trauma: Memory, hauntings, and the temporality of ruins." Memory Studies 2-1 (2009): 87-10. Doi: 10.1177/1750698008097397

\section{NOTES}

1. The excellence of Deraniyagala's well-charted academic itinerary given at the end of her autobiographical narrative of loss and survival contrasts sharply with the unbearable shock and the difficult and slow process of recovery that her book recounts. "Sonali Deraniyagala has an undergraduate degree in economics from Cambridge University and a doctorate in economics from the University of Oxford. She is on the faculty of the Department of Economics at the School of Oriental and African Studies, University of London, and is a research scholar at Columbia University." (Deraniyagala 2013: 213).

2. According to the ancient Sanskrit text of the Dharma Sutra, crossing the black waters of the ocean makes Hindus lose their social respectability and cultural roots.

3. As a piece of women's writing, the novel's title also indirectly alludes to Virginia Woolf's The Waves (1931). 
4. All references to Wave are indicated as follows: $\mathrm{Wx}$, where $\mathrm{x}$ is the page number.

5. All references to There is No Sea in Salford are indicated as follows: Sx, where $\mathrm{x}$ is the page number.

6. All references to A Little Dust in the Eyes are indicated as follows: LDEx, where $\mathrm{x}$ is the page number.

7. According to the founding myth of Sri Lanka, a Bengali princess married a lion. Out of this union was born Sinhabahu (who kills his own father) and his sister Sinhasivali. Their incestuous union gave birth to Vijaya, who was exiled to Lanka and had to build a new civilization. In 1961, the acclaimed Sri Lankan writer Ediriweera Sarachchandra wrote a play entitled Sinhabahu.

\section{ABSTRACTS}

The ancient Tamil epic Silappatikaram describes the flourishing portal city of Puhar and Manimekalai tells the story of how it was engulfed by the sea. The Sri Lankan chronicles Thupavamsa and Mahavamsa speak of another tsunami that was to have swallowed the kingdom of Kelani Tissa. The brave princess Vihara Mahadevi appeased the anger of nature that was intended for her father who had ill-treated a Buddhist monk by sacrificing herself. Surprisingly she survived. Almost two thousand years later, a daughter of the Island survives the tsunami of 2004 while tragically losing her parents, her husband and two sons in Wave (2013) by Sonali Deraniyagala. Deraniyagala's story about coping with loss and grief and surviving shuttles between two Islands - England and Sri Lanka. The love of Sri Lanka surfaces in the humanitarian approach of Dr. Philippa Hawley, a British physician who had performed her internship in Sri Lanka and published There's No Sea in Salford in 2013. The doctor-narrator Penny tries to reestablish contact with Kiri de Souza who was working as a nurse in the hospital where she did her internship in Sri Lanka and had married a Tamil doctor and settled in England. A story of liberation from cancer and domestic violence ensues that is enlarged and translated into a story of solidarity with the vulnerable in Sri Lanka. Minoli Salgado's A Little Dust in the Eyes (2014) evokes the close relationship between Renu and Savi, two cousins separated by civil war. During the trip to Sri Lanka from England undertaken to come to grips with her childhood, Savi is not able to retrieve anything but is helplessly swept away in the fatal swell of the sea. The aim of this paper is to first identify the type of narratives that insiders and outsiders choose to write when addressing the tsunami, then analyze what these tsunami narratives tell us about gender, family, ethnic, and race relations in times of personal, political and natural catastrophes. This paper finally explores how a pathway to peace is found across the geography of pain in these intimations of mortality.

L'ancienne épopée tamoule Silappatikaram évoque la ville portuaire prospère de Puhar et Manimekalai mentionne la vague mortelle qui l'avait engloutie. Les chroniques sri lankaises Thupavamsa et Mahavamsa parlent d'une autre vague qui devait avaler le royaume de Kelani Tissa. La brave princesse Vihara Mahadevi apaisât la colère de la nature destinée à son père qui avait maltraité un moine bouddhiste en se sacrifiant. Étonnamment, elle a survécu. Près de deux mille ans plus tard, une fille de l'île survit au tsunami de 2004 alors qu'elle perdait tragiquement ses parents, son mari et ses deux fils dans Wave (2013), un récit de Sonali Deraniyagala, où l'auteur raconte comment elle tente de faire face à la perte, au deuil et au vent-et-vient entre deux îles Angleterre et Sri Lanka - et de survivre. L'amour du Sri Lanka transparaît dans l'approche 
humanitaire du Dr Philippa Hawley, un médecin qui a effectué son stage au Sri Lanka, dans son roman There's No Sea in Salford (2013). La médecin-narratrice Penny essaie de rétablir le contact avec Kiri de Souza qui travaillait comme infirmière à l'hôpital où elle avait fait son stage, qui a ensuite épousé un médecin tamoul et s'est installée en Angleterre. Une histoire de libération du cancer et de la violence domestique s'ensuit et se traduit par un récit de solidarité avec les personnes vulnérables au Sri Lanka. A Little Dust in the Eyes de Minoli Salgado (2014) évoque la relation étroite entre Renu et Savi, deux cousines séparées par la guerre civile. Au cours de ce voyage au Sri Lanka entrepris en vue de se réconcilier avec son enfance, Savi n'est pas en mesure de récupérer quoi que ce soit et est balayée dans la houle mortifère de la mer. L'objectif de cette étude est d'abord d'identifier le type de récit que choisissent les auteures pour écrire le tsunami (avec un point de vue interne ou externe), puis d'analyser ce que ces récits du tsunami nous enseignent sur le genre, la famille, le groupe ethnique et les relations raciales en période de catastrophes personnelles, politiques et naturelles, et enfin de voir comment un chemin vers la paix se dessine à travers la géographie de la douleur dans ces intimations de la mortalité.

\section{INDEX}

Keywords: tsunami, narrative, trauma, survival, solidarity, childhood, migration, death, Sri Lanka, Deraniyagala Sonali, Hawley Philippa, Salgado Minoli

Mots-clés: tsunami, récit, trauma, survie, solidarité, enfance, migration, mort, Sri Lanka, Deraniyagala Sonali, Hawley Philippa, Salgado Minoli

\section{AUTHOR}

\section{GEETHA GANAPATHY-DORÉ}

Geetha Ganapathy-Doré is a Research Accredited Associate Professor of English at the Faculty of Law, Political and Social Sciences, University of Paris 13, Sorbonne Paris Cité. She is an active member of the CREA research centre at Nanterre University. She is the author of The Postcolonial Indian Novel in English (2011). She has coedited several books among which On the Move, The Journey of Refugees in New Literatures in English (2012) and Heritage and Ruptures in Indian Literature, Culture and Cinema (2017), published by Cambridge Scholars Publishing. Comme la pluie qui tombe sur la terre rouge is the title of her translation of some ancient Tamil poems published by Po\&Psy (2016). Her recent research revolves around India EU relations, Human Rights issues and Postcolonial cinema. She is the current President of SARI. Contact: geetha.dore[at]univ-paris13.fr 